Article

\title{
Priority of Accident Cause Based on Tower Crane Type for the Realization of Sustainable Management at Korean Construction Sites
}

\author{
Ju Yong Kim ${ }^{1}\left(\mathbb{D}\right.$, Don Soo Lee ${ }^{2}$, Jin Dong Kim ${ }^{3} \oplus$ and Gwang Hee Kim ${ }^{1, *}$ \\ 1 Department of Architectural Engineering, Kyonggi University, Yeongtong-Gu, Suwon 16227, Korea; \\ ju2020@kyonggi.ac.kr \\ 2 DAELIM Construction, 14, Miraero, Namdong-Gu, Incheon 21556, Korea; donandon14@hanmail.net \\ 3 Department of Architecture, Yeonsung University, Manan-Gu, Anyang-Si 14011, Korea; kjd@yeonsung.ac.kr \\ * Correspondence: ghkim@kyonggi.ac.kr; Tel.: +82-31-249-9757
}

Citation: Kim, J.Y.; Lee, D.S.; Kim, J.D.; Kim, G.H. Priority of Accident Cause Based on Tower Crane Type for the Realization of Sustainable Management at Korean Construction Sites. Sustainability 2021, 13, 242. https://doi.org/10.3390/su13010242

Received: 14 November 2020 Accepted: 25 December 2020 Published: 29 December 2020

Publisher's Note: MDPI stays neutral with regard to jurisdictional clai$\mathrm{ms}$ in published maps and institutional affiliations.

Copyright: (C) 2020 by the authors. Licensee MDPI, Basel, Switzerland. This article is an open access article distributed under the terms and conditions of the Creative Commons Attribution (CC BY) license (https:// creativecommons.org/licenses/by/ $4.0 /)$.

\begin{abstract}
Construction safety is a key factor among the many factors related to the sustainable management of construction sites. Although research is underway to reduce potential accidents in the construction industry in Korea, the number of tower crane (T/C) accidents is consistently increasing based on the increased use of such cranes. In this study, the priorities of accident causes for each T/C type were derived and utilized for the sustainable management of construction sites. An analytic hierarchy process (AHP) questionnaire was completed by experts such as construction engineers, construction managers, safety engineers, and $\mathrm{T} / \mathrm{C}$ operators with more than ten years of field experience. The results of the AHP questionnaire revealed that the leading cause of cab-control $\mathrm{T} / \mathrm{C}$ accidents is poor operator visibility, while the leading cause of accidents related to remote-control $\mathrm{T} / \mathrm{Cs}$ is the poor management of lifting objects and control of surroundings. The high-ranking causes derived in this study should be managed and priority measures should be implemented to reduce the number of $\mathrm{T} / \mathrm{C}$ accidents.
\end{abstract}

Keywords: sustainable construction management; tower crane accident reduction; priority of tower crane accident causes

\section{Introduction}

The crane has become a major symbol of building construction sites and is often the most prominent piece of equipment at a building construction site based on its size and the key role that it plays at many construction sites [1]. The use of tower cranes (T/Cs) at construction sites has consistently increased since their introduction into the Korean construction industry in the 1980s. According to statistics on construction machinery statuses from the Ministry of Land, Infrastructure, and Transport, in 2015, Korea contained 3408 cab-control (CC) T/Cs and 272 remote-control (RC) T/Cs. Generally, CC T/Cs are used for lifting objects weighing three tons or more and RC T/Cs are used for lifting objects weighing less than three tons. In 2019, the number of CC T/Cs increased by $22 \%$ to 4385 and the number of RC T/Cs increased by over $85 \%$ to 1845 [2].

One of the major causes of fatalities is the usage of cranes during lifting operations in the construction phase of the construction project lifecycle [3]. As the number of T/Cs used at construction sites has increased steadily, there has been an increase in fatalities and accidents because $\mathrm{T} / \mathrm{Cs}$ are relatively dangerous and various risk factors are inherent to assembly, lifting, and disassembly works [4]. As accidents at construction sites are closely related to construction time, cost, scope, and company reputation [5], and because construction workplace safety and health are essential elements of sustainable construction management [6], construction accidents must be reduced for the sustainable management of construction sites. Reyes et al. [7] stated that when quantifying the sustainable value of a construction project, health and safety indexes should be considered. Therefore, 
the government, academia, and practitioners in Korea have made various efforts to reduce $\mathrm{T} / \mathrm{C}$-related accidents. To reduce $\mathrm{T} / \mathrm{C}$ accidents, the Korean government revised the enforcement regulations of the Construction Equipment Management Act in October of 2019 , subdividing the safety training programs for construction equipment operators into 19 types and shortening the training cycle of RC T/C operators. Members of academia have also conducted research [8-10] on various causes of accident occurrence to reduce $\mathrm{T} / \mathrm{C}$ accidents.

Although many efforts have been made to prevent accidents related to CC T/Cs, research on $\mathrm{RC} \mathrm{T} / \mathrm{Cs}$, which are becoming increasingly common at Korean construction sites, is insufficient, leading to many accidents at construction sites. Every year, the number of T/C-related accidents at Korean construction sites continues to increase. The numbers of fatalities related to T/Cs were nine in 2016, seven in 2017, six in 2018, and eight in 2019 [11]. T/C accidents were officially announced during the first quarter of 2020, when five casualties had already occurred. Figure 1 presents an image from January 2 of 2020, where a $30 \mathrm{~m} \mathrm{~T} / \mathrm{C}$ collapsed at a construction site in Incheon, Korea. This accident caused two fatalities and one injury. Kim [12] analyzed T/Cs at Korean construction sites and proposed the following main accident causes: (1) In the case of CC T/Cs, the main causes are equipment age, insufficient work management, violation of work guidelines and safety rules, and lack of communication. (2) In the case of $\mathrm{RC} T / \mathrm{Cs}$, the main causes are a lack of knowledge regarding work manuals for installation workers, insufficient checking of the cables used for fixing lifted objects, a lack of simultaneous checking of camera feeds during tying and lifting work, and insufficient checking of the specifications of heavy objects.

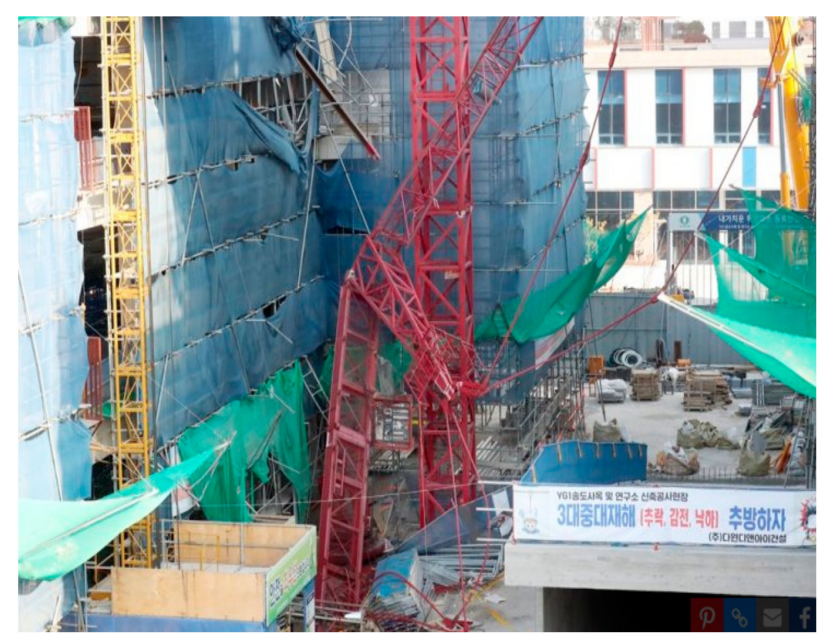

Figure 1. A $30 \mathrm{~m} \mathrm{~T} / \mathrm{C}$ (tower crane) collapse at a construction site in Incheon, Korea [5].

Therefore, this study aimed to identify whether ranking can be utilized for the accident causes' management of T/C types by analyzing the importance of accident causes for each crane type. The results of this study can contribute to reducing construction accidents by identifying management causes for $\mathrm{T} / \mathrm{Cs}$ that should be considered during the planning process for construction accident prevention and safety management activities.

\section{Literature Review}

\subsection{Previous Research}

Since the 2000s, various studies related to $\mathrm{T} / \mathrm{C}$ accidents have been conducted around the world. These studies can be classified into three major categories: (1) risk analysis for analyzing $\mathrm{T} / \mathrm{C}$ accidents $[13,14],(2)$ development of management goals or plans by analyzing $\mathrm{T} / \mathrm{C}$ accidents [14-16], (3) derivation of the major accident causes related to T/C accidents [17-21], and (4) presenting measures for preventing tower crane accidents [22]. Thus far, most studies have focused on the causes or risks of $\mathrm{T} / \mathrm{C}$ accidents based on specific causes and direct management. Especially, Fang et al. [22] developed a framework for 
real-time pro-active safety assistance (RPSA) for mobile crane lifting operation, and Zhang et al. [20] and Zhou et al. [21] presented the tower-crane accident cause system (TCACS) model, which was a quite logical model through system thinking and case analysis to quantify the tower crane accident causes. However, there was a limit to revealing the direct cause of $\mathrm{T} / \mathrm{C}$ accidents. Therefore, to reduce $\mathrm{T} / \mathrm{C}$ accidents, it is necessary to manage various accident causes that cause accidents comprehensively. In other words, it is necessary to manage the accident causes that cause accidents with a high frequency or high probability more intensively. Additionally, in Korea, the use of RC T/Cs has increased based on pressure from the $\mathrm{T} / \mathrm{C}$ union and the revision of the labor laws that limit working hours. Thus far, most research has focused on CC T/Cs, but there is a need to proceed with research to reduce all types of $\mathrm{T} / \mathrm{C}$ accidents, including $\mathrm{RC} \mathrm{T} / \mathrm{C}$ accidents.

\subsection{Construction Safety in Sustainability}

The area for sustainability appears to be focusing on limiting environmental impact, reducing energy, and incorporating less harmful material. Additionally, sustainability takes into account the environmental, economic, social and resource impacts of construction as well as the implementation of its principles throughout the lifecycle of building. However, Chandra [23] insisted that sustainable construction safety and health are an integral part of sustainable and environmentally friendly construction efforts. In addition, sustainable construction is defined as the creation of a healthy construction environment and responsible management based on resource efficiency and ecological principles. Rajendran et al. [24] recommended for research investigating the impact of green design and construction on worker safety and health, taking into account the safety and health of workers as well as the safety and health of the end user. Especially, the Leadership in Energy and Environmental Design (LEED) is designed to define eco-friendly buildings by establishing a common standard for measurement or rating systems and to achieve three main objectives: market innovation, design integration, and education on sustainable principles and sharing ideas [6]. Hinze et al. [6] presented the concept that worker safety and concern belong to education - the third plan of the LEED objectives. As mentioned, the sustainability certification, LEED, also includes worker safety in the construction process, and construction safety has become an indispensable item in sustainability.

\section{3. $T / C$ s at Construction Sites}

Cranes mainly used in the construction industry are classified into two equipment types: tower cranes and mobile cranes [1]. Mobile cranes can be classified as truck-mounted mobile crane and crawler crane. The basic truck-mounted crane configuration is a "boom truck" featuring a rear-mounted rotary telescopic boom crane mounted on a commercial truck. The crawler crane is boomed on a vehicle with a crawler track set that provides both stability and mobility. For many years, particularly in Korea, T/Cs have been widely used in all types of building construction projects in both urban and rural areas. In high-rise construction, $\mathrm{T} / \mathrm{C}$ s are a key type of equipment for moving materials, building elements, and form work components horizontally and vertically [1]. As shown in Figure 2, the major parts of the $\mathrm{T} / \mathrm{C}$ are the mast, main jib, and counter jib. The mast, which is a steel structure that serves as a pillar supporting the $\mathrm{T} / \mathrm{C}$, is constructed on the upper part of the basic mast, which is connected to the mounting configuration. Masts are available as rail-mounted units, stationary units, climbing units, and mobile units. Depending on whether the mast is fixed or slewing, a T/C can be classified as a fixed or a slewing T/C. Additionally, T/Cs can be classified as top-slewing and bottom-slewing $\mathrm{T} / \mathrm{C}$ s according to the $\mathrm{T} / \mathrm{C}$ rotation position. The $\mathrm{T} / \mathrm{C}$ cabin is attached to the crane structure or installed at a remote location. The cabin of a top-slewing crane is almost always at the top of the mast, often at a significant distance from the work area. In this type of crane, it is important to improve the quality of operator visibility. Bottom-slewing cranes do not have an operator cab attached to the crane structure. The main types of jibs on T/Cs are saddle jibs and luffing jibs. A saddle jib is supported by a pendant in a horizontal or near-horizontal position and the load hook 
changes the hook radius by moving along the jib on a trolley. A luffing jib rotates on the jib foot and is supported by a luffing cable. The load-bearing hoist rope typically passes through the sheave of the jib head and changes the hook radius by changing the inclination angle of the jib. A saddle jib typically has a smaller minimum working radius than an equivalent luffing jib, so it can handle loads closer to the crane tower. Many luffing jib cranes have very short counter jibs, which can be advantageous when a crane is operating near obstacles such as other cranes or adjacent buildings. In the case of Korean construction sites, CC T/Cs have dominated in the past, but RC T/Cs have been increasing in use rapidly in recent years. This trend appears to have been partially influenced by pressure from the $\mathrm{T} / \mathrm{C}$ operator union and construction labor union.

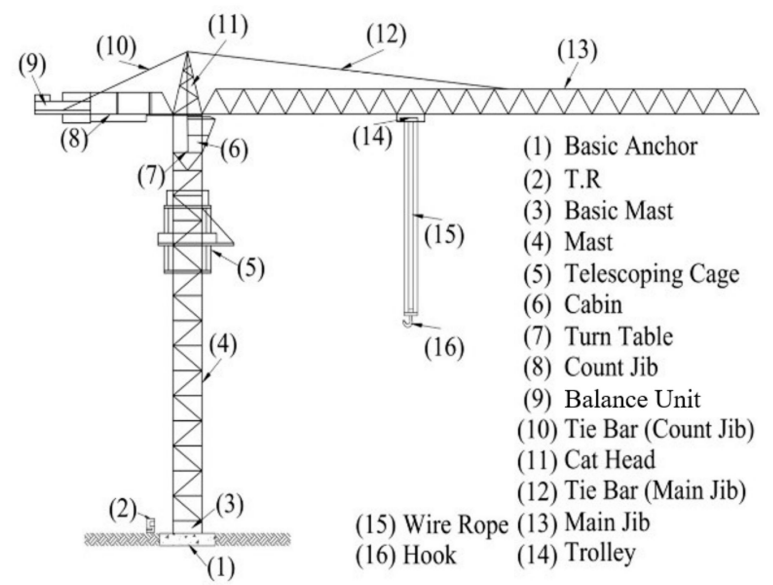

Figure 2. $\mathrm{T} / \mathrm{C}$ configuration.

\subsection{Types of $T / C$ Accidents}

The 40 tower crane accidents that occurred in Korea from 2015 to October 2020 were analyzed and classified into three categories such as the processes of erection, dismantling, and operation and management. The accident cases based on the analysis of T/C accident reports published from Korea Occupational Safety and Health Agency are the result of analyzing 40 accident cases - the most frequently occurred in the operation and management stage, 11 cases occurred in the erection stage, 7 cases in the dismantling stage, and 22 cases in the operation and management stage as shown in Table 1. Representative examples of each stage are as follows. In the erection stage, accidents related to eccentricity occur based on the operation of a T/C in a state where the telescopic component, mast, and other components are not fully fixed. Telescopic accidents break the balance of the jib while the telescopic mast is lifting or moving in an unstable state because the lower part of the turntable and upper pin of the telescopic cage are not fastened [25]. Collapse accidents occur because the member of the telescopic cage buckles based on improper use or non-use of a balance weight for the bidirectional balance of the jib during telescopic work [26]. Accidents in the dismantling stage are caused by the mast losing balance or the basic anchor being damaged. The position of the bolt hole for fixing the mast may be misaligned, so when an operator attempts to adjust the hole position, the crane may lose its balance and collapse. There can also be deviation between the cage roller and mast, causing a dismantling worker to disable the interlock function that stops crane operation. Forcible manipulation in this scenario can result in an accident [25]. Some accidents are also caused by the inadequate selection of standard lifting positions for dismantling, which causes the connecting part of the jib to split. During the process of $\mathrm{T} / \mathrm{C}$ operation and management, the causes of accidents are mainly non-compliance with the work procedures suggested by manufacturers and the negligence of management in terms of safety inspections and education. 
Table 1. T/C accident cases by construction phase/task.

\begin{tabular}{cccccc}
\hline Year & $\mathbf{2 0 1 7}$ & $\mathbf{2 0 1 8}$ & $\mathbf{2 0 1 9}$ & $\mathbf{2 0 2 0 . 1 0}$ & Total \\
\hline Erection & 2 & 3 & 3 & 3 & 11 \\
\hline Dismantling & 2 & 1 & 3 & 1 & 7 \\
\hline Operation and management & 5 & 5 & 6 & 6 & 22 \\
\hline Total & 9 & 9 & 12 & 10 & 40 \\
\hline
\end{tabular}

\section{Methods}

This study aimed to derive the importance of $\mathrm{T} / \mathrm{C}$ accident causes and the potential for $\mathrm{T} / \mathrm{C}$ accidents by quantifying the experiences of experts related to construction accidents. Intensively managing such factors should aid in reducing $\mathrm{T} / \mathrm{C}$ accidents. The analytic hierarchy process (AHP) technique was adopted to quantify the experiences of experts related to construction accidents in the field. The AHP is a structured decision-making technique developed by Saaty in the early 1970s. It can reflect the knowledge, experience, and intuition of respondents in pair-wise comparisons based on the elements of the hierarchy of decision-making [27]. The experts related to construction accidents for the AHP are construction engineers, construction managers, safety managers, and $\mathrm{T} / \mathrm{C}$ operators that have more than 10 years of field experience.

As shown in Figure 3, this research process can be divided into the following 4 steps. (1) Identify major T/C accidents through a literature review. (2) Extract first-level phase/task and second-level structure accident causes for the AHP through interviews with related experts. After extracting 11 phases/tasks from the previous literature [12,14,15,18,19,21,28], 5 items were selected by integrating 11 items through interviews with the related experts. For the second-level accident causes, 15 items were selected by conducting a preliminary survey of accident causes extracted from the previous literature (refer to Table 2) as a Likert scale to the related experts, and the results are presented in Table 3. (3) Provide an AHP questionnaire to a total of 44 related experts, such as construction managers, 10 safety managers, 14 construction engineers, and $10 \mathrm{~T} / \mathrm{C}$ operators. (4) Follow the AHP to derive priority management accident causes for reducing $\mathrm{T} / \mathrm{C}$ accidents. 


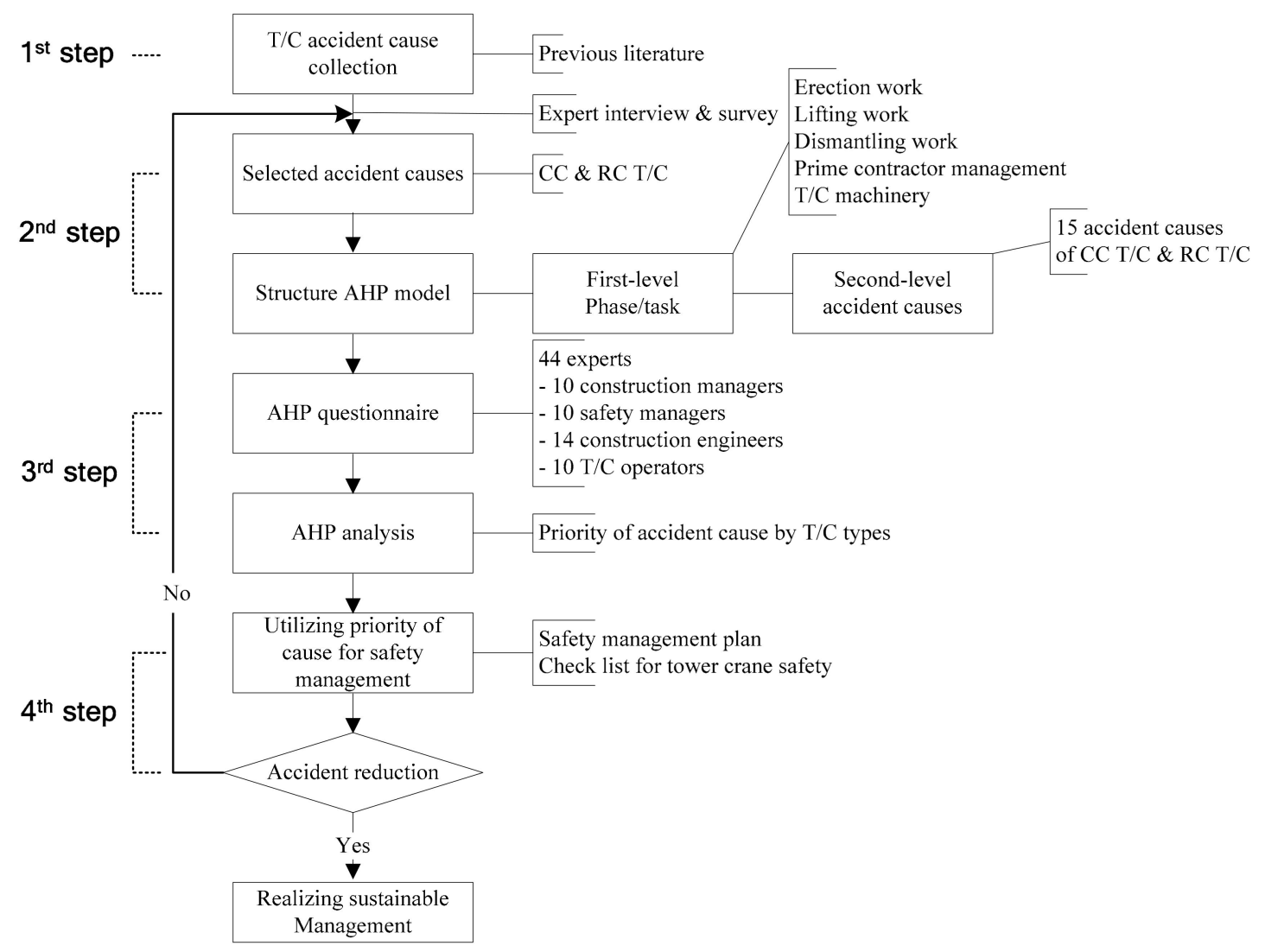

Figure 3. Developed model and research process.

Table 2. Causes of the AHP (analytic hierarchy process) model for T/C accidents.

\begin{tabular}{|c|c|c|}
\hline First Level Phase/Task & $\begin{array}{l}\text { Second-Level (Sub) Accident Causes of the } \\
\text { AHP Structure for T/C Accidents }\end{array}$ & Reference \\
\hline \multirow{3}{*}{ Erection work } & $\begin{array}{c}\text { Improper bolting on the brace/mast/telescopic } \\
\text { element }\end{array}$ & Kwon (2015), Cho (2017), Wei et al. (2018) \\
\hline & $\begin{array}{l}\text { Failure to comply with safety rules and work } \\
\text { guidelines for erection work }\end{array}$ & $\begin{array}{l}\text { Kwon (2015), Cho (2017), Song (2018), } \\
\text { in (2018) }\end{array}$ \\
\hline & Insufficient worker skill for erection work & In (2018) and Song (2018) \\
\hline \multirow{3}{*}{ Dismantling work } & $\begin{array}{l}\text { Poor understanding of accident risk during the } \\
\text { dismantling process }\end{array}$ & $\begin{array}{l}\text { Vivian and Ivan (2011), Heng et al. (2012), } \\
\text { Kwon (2015), Song (2018), in (2018) }\end{array}$ \\
\hline & Improper tightening of bolts & Cho (2017), Song (2018), in (2018) \\
\hline & Low skill level of dismantling workers & $\begin{array}{l}\text { Vivian and Ivan (2011), Heng et al. (2012), } \\
\text { Kwon (2015), Cho (2017), Song (2018) }\end{array}$ \\
\hline \multirow{5}{*}{ Lifting work } & $\begin{array}{c}\text { Poor management of lifting objects and control } \\
\text { of surroundings }\end{array}$ & Kwon (2015), Cho (2017), Song (2018) \\
\hline & Improper tying of the sling leg & Kwon (2015), Cho (2017), Song (2018) \\
\hline & Poor operator visibility & Cho (2017) and Kim (2018) \\
\hline & $\begin{array}{l}\text { Operator unable to check the weight and } \\
\text { specifications of the lifted objects }\end{array}$ & Kim (2018) \\
\hline & Operator cannot check the wire and sling leg & Kim (2018) \\
\hline
\end{tabular}


Table 2. Cont.

\begin{tabular}{|c|c|c|}
\hline First Level Phase/Task & $\begin{array}{l}\text { Second-Level (Sub) Accident Causes of the } \\
\text { AHP Structure for T/C Accidents }\end{array}$ & Reference \\
\hline \multirow{3}{*}{ Prime contractor management } & $\begin{array}{l}\text { Inappropriate personnel and equipment } \\
\text { placement }\end{array}$ & Kwon (2015) and Cho (2017) \\
\hline & $\begin{array}{l}\text { Poor subcontracting technology management } \\
\text { process }\end{array}$ & $\begin{array}{l}\text { Vivian and Ivan (2011), Kwon (2015), Cho } \\
\text { (2017), Wei et al. (2018) }\end{array}$ \\
\hline & $\begin{array}{l}\text { Insufficient safety management of equipment } \\
\text { and personnel }\end{array}$ & Kwon (2015), Cho (2017), Wei et al. (2018) \\
\hline \multirow{3}{*}{$\mathrm{T} / \mathrm{C}$ machinery } & Equipment aging & Cho (2017) and Kim (2018) \\
\hline & Crane operation error or failure & Cho (2017) and In (2018) \\
\hline & Problems with overseas parts procurement & Cho (2017) \\
\hline
\end{tabular}

Table 3. Preliminary survey results of accident causes.

\begin{tabular}{|c|c|c|c|}
\hline \multicolumn{2}{|c|}{ Figure } & Second-Level (Sub) Causes for T/C Accidents & Ranking \\
\hline \multirow{5}{*}{\multicolumn{2}{|c|}{ Erection work }} & Failure to comply with safety rules and work guidelines for erection work & 1 \\
\hline & & Insufficient worker skill for erection work & 2 \\
\hline & & Bad bolting brace/mast/telescopic element & 3 \\
\hline & & Not used seat belt during erection work & 4 \\
\hline & & Asymmetric load due to deflected foundation anchor & 5 \\
\hline \multirow{5}{*}{\multicolumn{2}{|c|}{ Dismantling work }} & Poor understanding of accident risk during the dismantling process & 1 \\
\hline & & Low skill level of dismantling workers & 2 \\
\hline & & Poor tightening of bolts & 3 \\
\hline & & Jib imbalance or damage & 4 \\
\hline & & Non-compliance with manufacturer's instruction and work order & 5 \\
\hline \multirow{10}{*}{ Lifting work } & & Poor operator visibility & 1 \\
\hline & & Poor management of lifting objects and control of surroundings & 2 \\
\hline & $\mathrm{CC} \mathrm{T/C}$ & Poor tying of the sling leg & 3 \\
\hline & & Bad signal & 4 \\
\hline & & Equipment defect & 5 \\
\hline & \multirow{5}{*}{$\mathrm{RC} \mathrm{T} / \mathrm{C}$} & Operator cannot check the wire and sling leg & 1 \\
\hline & & Operator unable to check the weight and specifications of the lifted objects & 2 \\
\hline & & Poor management of lifting objects and control of surroundings & 3 \\
\hline & & Bad signal & 4 \\
\hline & & Equipment defect & 5 \\
\hline \multirow{5}{*}{\multicolumn{2}{|c|}{ Prime contractor management }} & Inappropriate personnel and equipment placement & 1 \\
\hline & & Insufficient safety management of equipment and personnel & 2 \\
\hline & & Poor subcontracting technology management process & 3 \\
\hline & & Improper risk assessment & 4 \\
\hline & & Equipment maintenance history unconfirmed & 5 \\
\hline \multirow{5}{*}{\multicolumn{2}{|c|}{$\mathrm{T} / \mathrm{C}$ machinery }} & Aging equipment & 1 \\
\hline & & Problems with overseas parts procurement & 2 \\
\hline & & Crane operation error or failure & 3 \\
\hline & & Design and construction errors & 4 \\
\hline & & Insufficient electrical insulation & 5 \\
\hline
\end{tabular}

\section{AHP Model for T/C Accident Factors}

\subsection{Extract T/C Accident Factors and Structure of the AHP Model}

Major causes were extracted by interviewing related experts, such as construction managers, safety managers, and construction engineers, after arranging the causes of 
$\mathrm{T} / \mathrm{C}$ accidents discussed in the previous literature. Expert interviews for classifying the extracted major phases/tasks and causes, and identifying first-level phases/tasks and second-level causes were conducted to structure the hierarchy of the AHP model. The firstlevel phase/task in the AHP model are five categories of dismantling work, lifting work, erection work, prime contractor management, and T/C machinery (Figure 4). Table 3 lists a total of five first-level phases/tasks and second-level accident causes that were extracted from the previous literature based on expert interviews and preliminary surveys. These accident causes were used in our AHP model for T/C accidents.

\subsection{Structure of the AHP Model}

Figure 4 presents an AHP model for CC T/Cs and RC T/Cs. F1 to F5 in Figure 4 represent the first-level phase/task. Among the second-level accident causes for lifting management, F21 is applicable to both types of cranes, whereas F22 and F23 are relevant to CC T/Cs, and F24 and F25 are relevant to RC T/Cs.

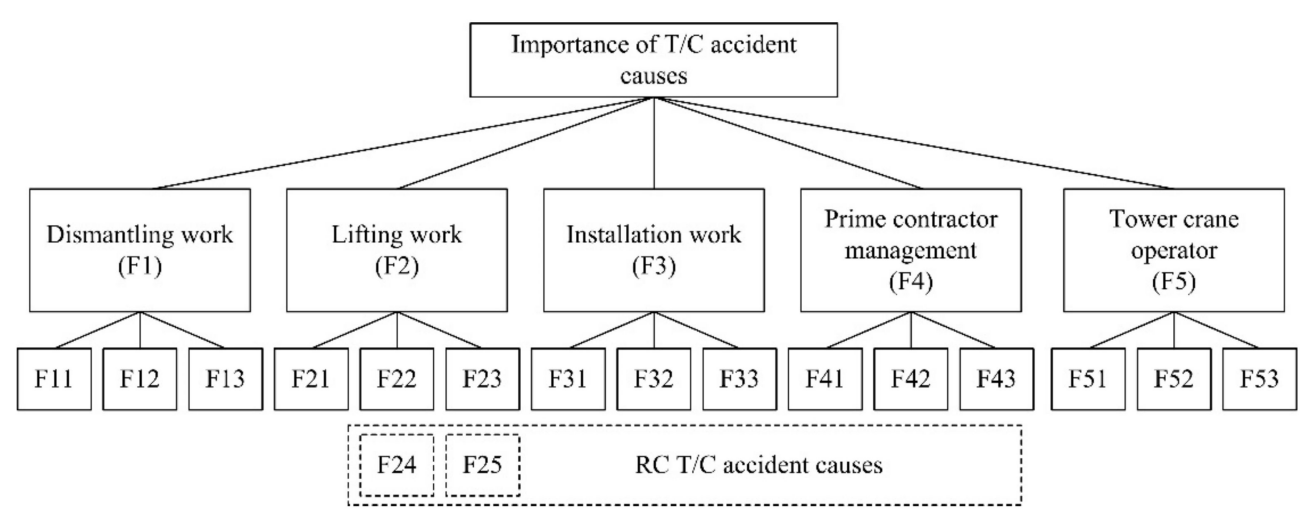

Figure 4. AHP structure for $\mathrm{T} / \mathrm{C}$ accidents.

\subsection{AHP Survey}

The analysis results for the AHP questionnaire are presented in Table 4. The weights of the first-level phase/task indicate that erection work is the most important phase/task with a value of 0.226 , followed by T/C machinery (0.216), lifting work (0.214), and prime contractor management (0.175), while dismantling work is the least important with a value of 0.170 for CC T/Cs. In the case of RC T/Cs, lifting work is the most important phase/task with a value of 0.264 , followed by erection work (0.254), dismantling work (0.170), and T/C machinery (0.167). Prime contractor management has the lowest value of 0.146 .

Table 4. Weight ranking of first-level phase/task in the AHP model.

\begin{tabular}{|c|c|c|c|c|c|c|c|c|c|c|c|}
\hline \multirow{2}{*}{\multicolumn{2}{|c|}{ Phase/Task }} & \multirow{2}{*}{\multicolumn{2}{|c|}{$\begin{array}{c}\begin{array}{c}\text { Construction } \\
\text { Engineer }\end{array} \\
\mathbf{W t}{ }^{*} \\
\end{array}$}} & \multirow{2}{*}{\multicolumn{2}{|c|}{$\begin{array}{c}\begin{array}{c}\text { Construction } \\
\text { Manager }\end{array} \\
\mathbf{R}^{* *} \\
\end{array}$}} & \multirow{2}{*}{\multicolumn{2}{|c|}{$\begin{array}{c}\begin{array}{c}\text { Safety } \\
\text { Engineer }\end{array} \\
\mathrm{Wt}\end{array}$}} & \multirow{2}{*}{\multicolumn{2}{|c|}{$\begin{array}{c}\begin{array}{c}\mathrm{T} / \mathrm{C} \\
\text { Operator }\end{array} \\
\mathbf{R}\end{array}$}} & \multirow{2}{*}{\multicolumn{2}{|c|}{$\begin{array}{c}\text { Total } \\
\mathbf{W t}\end{array}$}} \\
\hline & & & & & & & & & & & \\
\hline \multirow{5}{*}{$\mathrm{CC} \mathrm{T/C}$} & Erection work & 0.156 & 3 & 0.205 & 3 & 0.219 & 3 & 0.322 & 1 & 0.226 & 1 \\
\hline & Dismantling work & 0.391 & 1 & 0.090 & 5 & 0.100 & 5 & 0.099 & 5 & 0.170 & 5 \\
\hline & Lifting work & 0.294 & 2 & 0.293 & 1 & 0.121 & 4 & 0.146 & 4 & 0.214 & 3 \\
\hline & Prime contractor management & 0.087 & 4 & 0.164 & 4 & 0.254 & 2 & 0.194 & 3 & 0.175 & 4 \\
\hline & $\mathrm{T} / \mathrm{C}$ machinery & 0.072 & 5 & 0.248 & 2 & 0.305 & 1 & 0.239 & 2 & 0.216 & 2 \\
\hline \multirow{5}{*}{$\mathrm{RC} \mathrm{T} / \mathrm{C}$} & Erection work & 0.155 & 3 & 0.279 & 2 & 0.181 & 2 & 0.399 & 1 & 0.254 & 2 \\
\hline & Dismantling work & 0.390 & 1 & 0.116 & 4 & 0.123 & 3 & 0.050 & 5 & 0.170 & 3 \\
\hline & Lifting work & 0.296 & 2 & 0.094 & 5 & 0.577 & 1 & 0.091 & 4 & 0.264 & 1 \\
\hline & Prime contractor management & 0.086 & 4 & 0.219 & 3 & 0.092 & 4 & 0.185 & 3 & 0.146 & 5 \\
\hline & $\mathrm{T} / \mathrm{C}$ machinery & 0.073 & 5 & 0.292 & 1 & 0.027 & 5 & 0.275 & 2 & 0.167 & 4 \\
\hline
\end{tabular}


The analysis results for the AHP questionnaire on the second-level causes of T/C accidents are presented in Table 5. The weights of the second-level causes for CC T/Cs appear from largest to smallest as follows: poor operator visibility, improper bolting of the brace/mast/telescopic element, poor subcontracting technology management process, failure to comply with safety rules and work guidelines for erection work, problems with overseas parts procurement, and poor understanding of risk factors during the dismantling process. As shown in Table 5, in the case of RC T/Cs, poor management of lifted objects and control of surroundings are the most important causes, followed by the operator being unable to check the weight and specifications of the lifted objects, failure to comply with safety rules and work guidelines for erection work, insufficient worker skill for erection work, and improper bolting of the brace/mast/telescopic element.

Table 5. Weight ranking of second-level accident causes in the AHP model.

\begin{tabular}{|c|c|c|c|c|c|c|c|c|c|c|c|c|}
\hline \multicolumn{2}{|c|}{ First Level } & \multirow[t]{2}{*}{ Second Level } & \multicolumn{2}{|c|}{$\begin{array}{l}\text { Construction } \\
\text { Engineer }\end{array}$} & \multicolumn{2}{|c|}{$\begin{array}{c}\text { Construction } \\
\text { Manager }\end{array}$} & \multicolumn{2}{|c|}{$\begin{array}{c}\text { Safety } \\
\text { Engineer }\end{array}$} & \multicolumn{2}{|c|}{$\begin{array}{c}\mathrm{T} / \mathrm{C} \\
\text { Operator }\end{array}$} & \multicolumn{2}{|c|}{ Total } \\
\hline & & & Wt. & $\mathbf{R}$ & Wt. & $\mathbf{R}$ & Wt. & $\mathbf{R}$ & Wt. & $\mathbf{R}$ & Wt. & $\mathbf{R}$ \\
\hline \multirow{3}{*}{\multicolumn{2}{|c|}{ Erection work }} & $\begin{array}{l}\text { Improper bolting on the } \\
\text { brace/mast/telescopic } \\
\text { element }\end{array}$ & 0.081 & 5 & 0.122 & 2 & 0.126 & 2 & 0.116 & 3 & 0.098 & 2 \\
\hline & & $\begin{array}{c}\text { Failure to comply with } \\
\text { safety rules and work } \\
\text { guidelines for erection } \\
\text { work }\end{array}$ & 0.040 & 9 & 0.057 & 7 & 0.054 & 9 & 0.180 & 1 & 0.080 & 4 \\
\hline & & $\begin{array}{l}\text { Insufficient worker skill for } \\
\text { erection work }\end{array}$ & 0.036 & 10 & 0.027 & 14 & 0.040 & 11 & 0.085 & 6 & 0.046 & 13 \\
\hline \multirow{12}{*}{$\mathrm{CC} \mathrm{T/C}$} & \multirow{3}{*}{$\begin{array}{l}\text { Dismantling } \\
\text { work }\end{array}$} & $\begin{array}{l}\text { Poor understanding of } \\
\text { accident risk during } \\
\text { dismantling process }\end{array}$ & 0.204 & 1 & 0.039 & 10 & 0.028 & 12 & 0.048 & 8 & 0.073 & 6 \\
\hline & & $\begin{array}{l}\text { Improper tightening of } \\
\text { bolts }\end{array}$ & 0.066 & 6 & 0.030 & 13 & 0.052 & 10 & 0.011 & 15 & 0.048 & 12 \\
\hline & & $\begin{array}{l}\text { Low skill level of } \\
\text { dismantling workers }\end{array}$ & 0.121 & 3 & 0.021 & 15 & 0.020 & 13 & 0.040 & 10 & 0.049 & 11 \\
\hline & \multirow[t]{3}{*}{ Lifting work } & $\begin{array}{l}\text { Poor management of lifting } \\
\text { objects and control of } \\
\text { surroundings }\end{array}$ & 0.042 & 8 & 0.117 & 4 & 0.015 & 14 & 0.096 & 4 & 0.071 & 8 \\
\hline & & $\begin{array}{l}\text { Improper tying of the sling } \\
\text { leg }\end{array}$ & 0.107 & 4 & 0.041 & 9 & 0.012 & 15 & 0.011 & 14 & 0.037 & 15 \\
\hline & & Poor operator visibility & 0.144 & 2 & 0.135 & 1 & 0.093 & 4 & 0.039 & 11 & 0.107 & 1 \\
\hline & \multirow{3}{*}{$\begin{array}{c}\text { Prime } \\
\text { contractor } \\
\text { management }\end{array}$} & $\begin{array}{l}\text { Inappropriate personnel } \\
\text { and equipment placement }\end{array}$ & 0.018 & 14 & 0.039 & 11 & 0.067 & 7 & 0.044 & 9 & 0.042 & 14 \\
\hline & & $\begin{array}{l}\text { technology management } \\
\text { process }\end{array}$ & 0.047 & 7 & 0.036 & 12 & 0.123 & 3 & 0.131 & 2 & 0.084 & 3 \\
\hline & & $\begin{array}{l}\text { Insufficient safety } \\
\text { management of equipment } \\
\text { and personnel }\end{array}$ & 0.022 & 13 & 0.089 & 5 & 0.064 & 8 & 0.019 & 13 & 0.050 & 10 \\
\hline & \multirow{3}{*}{$\mathrm{T} / \mathrm{C}$ machine } & Equipment aging & 0.023 & 12 & 0.119 & 3 & 0.079 & 5 & 0.079 & 7 & 0.064 & 9 \\
\hline & & $\begin{array}{l}\text { Crane operation error or } \\
\text { failure }\end{array}$ & 0.018 & 15 & 0.083 & 6 & 0.075 & 6 & 0.026 & 12 & 0.071 & 7 \\
\hline & & $\begin{array}{l}\text { Problems with overseas } \\
\text { parts procurement }\end{array}$ & 0.031 & 11 & 0.047 & 8 & 0.152 & 1 & 0.090 & 5 & 0.075 & 5 \\
\hline
\end{tabular}


Table 5. Cont.

\begin{tabular}{|c|c|c|c|c|c|c|c|c|c|c|c|c|}
\hline \multicolumn{2}{|c|}{ First Level } & \multirow[t]{2}{*}{ Second Level } & \multicolumn{2}{|c|}{$\begin{array}{c}\text { Construction } \\
\text { Engineer }\end{array}$} & \multicolumn{2}{|c|}{$\begin{array}{c}\text { Construction } \\
\text { Manager }\end{array}$} & \multicolumn{2}{|c|}{$\begin{array}{c}\text { Safety } \\
\text { Engineer }\end{array}$} & \multicolumn{2}{|c|}{$\begin{array}{c}\mathrm{T} / \mathrm{C} \\
\text { Operator }\end{array}$} & \multicolumn{2}{|c|}{ Total } \\
\hline & & & Wt. & $\mathbf{R}$ & Wt. & $\mathbf{R}$ & Wt. & $\mathbf{R}$ & Wt. & $\mathbf{R}$ & Wt. & $\mathbf{R}$ \\
\hline \multirow{3}{*}{\multicolumn{2}{|c|}{ Erection work }} & $\begin{array}{c}\text { Improper bolting on the } \\
\text { brace/mast/telescopic } \\
\text { element }\end{array}$ & 0.080 & 5 & 0.107 & 4 & 0.048 & 8 & 0.061 & 6 & 0.084 & 5 \\
\hline & & $\begin{array}{c}\text { Failure to comply with } \\
\text { safety rules and work } \\
\text { guidelines for erection } \\
\text { work }\end{array}$ & 0.039 & 8 & 0.127 & 3 & 0.058 & 5 & 0.134 & 3 & 0.086 & 3 \\
\hline & & $\begin{array}{l}\text { Insufficient worker skill for } \\
\text { erection work }\end{array}$ & 0.036 & 10 & 0.046 & 6 & 0.075 & 4 & 0.204 & 1 & 0.084 & 4 \\
\hline \multirow{12}{*}{$\mathrm{RC} T / \mathrm{C}$} & \multirow{3}{*}{$\begin{array}{l}\text { Dismantling } \\
\text { work }\end{array}$} & $\begin{array}{l}\text { Poor understanding of } \\
\text { accident risk during } \\
\text { dismantling process }\end{array}$ & 0.186 & 1 & 0.015 & 15 & 0.039 & 9 & 0.009 & 14 & 0.047 & 12 \\
\hline & & $\begin{array}{l}\text { Improper tightening of } \\
\text { bolts }\end{array}$ & 0.082 & 4 & 0.044 & 11 & 0.032 & 10 & 0.007 & 15 & 0.042 & 13 \\
\hline & & $\begin{array}{l}\text { Low skill level of } \\
\text { dismantling workers }\end{array}$ & 0.122 & 3 & 0.057 & 5 & 0.051 & 7 & 0.034 & 10 & 0.081 & 7 \\
\hline & \multirow[t]{3}{*}{ Lifting work } & $\begin{array}{l}\text { Poor management of lifting } \\
\text { objects and control of } \\
\text { surroundings }\end{array}$ & 0.178 & 2 & 0.033 & 13 & 0.311 & 1 & 0.010 & 13 & 0.105 & 1 \\
\hline & & $\begin{array}{l}\text { Operator unable to check } \\
\text { the weight and } \\
\text { specifications of the lifted } \\
\text { objects }\end{array}$ & 0.062 & 6 & 0.040 & 12 & 0.082 & 3 & 0.071 & 5 & 0.103 & 2 \\
\hline & & $\begin{array}{l}\text { Operator cannot check the } \\
\text { wire and sling leg }\end{array}$ & 0.057 & 7 & 0.022 & 14 & 0.185 & 2 & 0.011 & 12 & 0.057 & 9 \\
\hline & \multirow{3}{*}{$\begin{array}{c}\text { Prime } \\
\text { contractor } \\
\text { management }\end{array}$} & $\begin{array}{l}\text { Inappropriate personnel } \\
\text { and equipment placement }\end{array}$ & 0.019 & 14 & 0.045 & 9 & 0.020 & 11 & 0.037 & 9 & 0.031 & 15 \\
\hline & & $\begin{array}{l}\text { technology management } \\
\text { process }\end{array}$ & 0.036 & 11 & 0.045 & 10 & 0.052 & 6 & 0.111 & 4 & 0.065 & 8 \\
\hline & & $\begin{array}{l}\text { Insufficient safety } \\
\text { management of equipment } \\
\text { and personnel }\end{array}$ & 0.031 & 12 & 0.130 & 2 & 0.020 & 12 & 0.037 & 8 & 0.050 & 11 \\
\hline & \multirow{3}{*}{$\mathrm{T} / \mathrm{C}$ machine } & Equipment aging & 0.010 & 15 & 0.200 & 1 & 0.005 & 14 & 0.061 & 7 & 0.052 & 10 \\
\hline & & $\begin{array}{l}\text { Crane operation error or } \\
\text { failure }\end{array}$ & 0.024 & 13 & 0.046 & 7 & 0.005 & 15 & 0.025 & 11 & 0.032 & 14 \\
\hline & & $\begin{array}{l}\text { Problems with overseas } \\
\text { parts procurement }\end{array}$ & 0.039 & 9 & 0.046 & 8 & 0.017 & 13 & 0.189 & 2 & 0.083 & 6 \\
\hline
\end{tabular}

\section{Case Study}

Since it is difficult to measure the rate of reduction in accident causes by applying the results of this AHP analysis to actual construction sites, we propose the reduction rate of accident causes through the scenario of installing a camera and wireless transmitter on the trolley of tower cranes and also placing a safety manager of tower crane (refer to Figure 5). In this scenario, it is assumed that the tower crane operator (both CC T/C and RC T/C), the safety manager of tower crane, and the field office have installed monitors that can check the lifting work of the tower crane. As shown in Table 6, the weight calculated in AHP analysis was converted into the probability of accident causes in order to calculate the reduction rate of accident causes. The probability of erection phase is $22 \%$ for CC $\mathrm{T} / \mathrm{C}$ and $25 \%$ for RC T/C. Dismantling phase is $17 \%$ for both T/C and Lifting work; is $22 \%$ for CC T/C and $27 \%$ for RC T/C and prime contractor management; is $17 \%$ for CC 
$\mathrm{T} / \mathrm{C}$ and $15 \%$ for RC T/C and T/C machinery; is $22 \%$ for CC T/C and $16 \%$ for RC T/C. As shown in Table 6, in the case of installing the camera to tower crane for tower crane operator, the safety manager of tower crane and field office, most of the accident causes are eliminated, so that the reduction probability for CC T/C is $29 \%$ and RC T/C is $30 \%$. In the case of placing the safety manager of tower crane, the reduction probability for $\mathrm{CC} \mathrm{T} / \mathrm{C}$ is $55 \%$ and RC T/C is $49 \%$. Although this reduction probability is not the result obtained after applying two cases to the actual construction site, it is believed that the camera attached to tower crane and safety manager of tower crane can eliminate most of the actual causes of tower crane accidents.

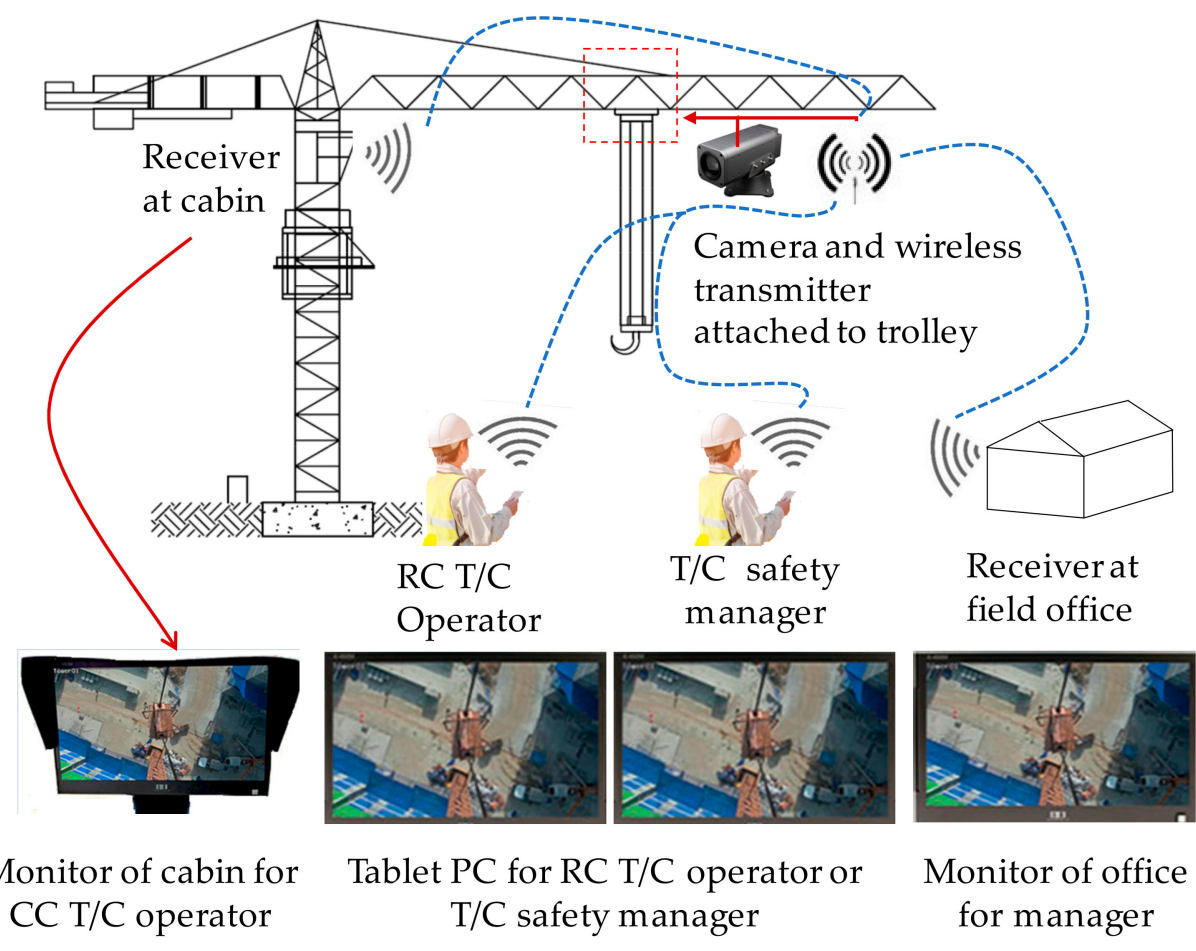

Figure 5. Safety camera and wireless transmission for preventing tower crane accidents.

Table 6. Accident probability and reduction probability applied to T/C camera and manager.

\begin{tabular}{|c|c|c|c|c|c|c|c|c|c|}
\hline \multirow{3}{*}{$\begin{array}{l}\text { First Level } \\
\text { Phase/Task }\end{array}$} & \multirow{3}{*}{$\begin{array}{l}\text { Second-Level (Sub) Accident } \\
\text { Causes of the AHP Structure for T/C } \\
\text { Accidents }\end{array}$} & \multirow{2}{*}{\multicolumn{2}{|c|}{$\begin{array}{l}\text { Weights by } \\
\text { AHP Analysis }\end{array}$}} & \multirow{2}{*}{\multicolumn{2}{|c|}{$\begin{array}{l}\text { Probability by } \\
\text { AHP Analysis }\end{array}$}} & \multicolumn{4}{|c|}{ Reduction Probability } \\
\hline & & & & & & \multicolumn{2}{|c|}{ Safety Camera } & \multicolumn{2}{|c|}{ T/C Manager } \\
\hline & & $\begin{array}{l}\mathrm{CC} \\
\mathrm{T} / \mathrm{C}\end{array}$ & $\begin{array}{l}\mathrm{RC} \\
\mathrm{T} / \mathrm{C}\end{array}$ & $\begin{array}{l}\mathrm{CC} \\
\mathrm{T} / \mathrm{C}\end{array}$ & $\begin{array}{l}\mathrm{RC} \\
\mathrm{T} / \mathrm{C}\end{array}$ & $\begin{array}{l}\mathrm{CC} \\
\mathrm{T} / \mathrm{C}\end{array}$ & $\begin{array}{l}\mathrm{RC} \\
\mathrm{T} / \mathrm{C}\end{array}$ & $\begin{array}{l}\mathrm{CC} \\
\mathrm{T} / \mathrm{C}\end{array}$ & $\begin{array}{l}\mathrm{RC} \\
\mathrm{T} / \mathrm{C}\end{array}$ \\
\hline \multirow{4}{*}{ Erection work } & $\begin{array}{l}\text { Improper bolting on the } \\
\text { brace/mast/telescopic element }\end{array}$ & 0.098 & 0.084 & 10 & 8 & 0 & 0 & 10 & 8 \\
\hline & $\begin{array}{l}\text { Failure to comply with safety rules } \\
\text { and work guidelines for erection } \\
\text { work }\end{array}$ & 0.080 & 0.086 & 8 & 9 & 0 & 0 & 8 & 9 \\
\hline & $\begin{array}{l}\text { Insufficient worker skill for erection } \\
\text { work }\end{array}$ & 0.046 & 0.084 & 4 & 8 & 0 & 0 & 0 & 0 \\
\hline & Subtotal & & & 22 & 25 & 0 & 0 & 18 & 17 \\
\hline \multirow{4}{*}{$\begin{array}{l}\text { Dismantling } \\
\text { work }\end{array}$} & $\begin{array}{l}\text { Poor understanding of accident risk } \\
\text { during the dismantling process }\end{array}$ & 0.073 & 0.047 & 7 & 5 & 0 & 0 & 7 & 5 \\
\hline & Improper tightening of bolts & 0.048 & 0.042 & 5 & 4 & 0 & 0 & 5 & 4 \\
\hline & $\begin{array}{c}\text { Low skill level of dismantling } \\
\text { workers }\end{array}$ & 0.049 & 0.081 & 5 & 8 & 0 & 0 & 0 & 0 \\
\hline & Subtotal & & & 17 & 17 & 0 & 0 & 12 & 9 \\
\hline
\end{tabular}


Table 6. Cont.

\begin{tabular}{|c|c|c|c|c|c|c|c|c|c|}
\hline \multirow{3}{*}{$\begin{array}{l}\text { First Level } \\
\text { Phase/Task }\end{array}$} & \multirow{3}{*}{$\begin{array}{c}\text { Second-Level (Sub) Accident } \\
\text { Causes of the AHP Structure for T/C } \\
\text { Accidents }\end{array}$} & \multirow{2}{*}{\multicolumn{2}{|c|}{$\begin{array}{l}\text { Weights by } \\
\text { AHP Analysis }\end{array}$}} & \multirow{2}{*}{\multicolumn{2}{|c|}{$\begin{array}{l}\text { Probability by } \\
\text { AHP Analysis }\end{array}$}} & \multicolumn{4}{|c|}{ Reduction Probability } \\
\hline & & & & & & \multicolumn{2}{|c|}{ Safety Camera } & \multicolumn{2}{|c|}{ T/C Manager } \\
\hline & & $\begin{array}{l}\mathrm{CC} \\
\mathrm{T} / \mathrm{C}\end{array}$ & $\begin{array}{l}\mathrm{RC} \\
\mathrm{T} / \mathrm{C}\end{array}$ & $\begin{array}{l}\mathrm{CC} \\
\mathrm{T} / \mathrm{C}\end{array}$ & $\begin{array}{l}\mathrm{RC} \\
\mathrm{T} / \mathrm{C}\end{array}$ & $\begin{array}{l}\mathrm{CC} \\
\mathrm{T} / \mathrm{C}\end{array}$ & $\begin{array}{l}\mathrm{RC} \\
\mathrm{T} / \mathrm{C}\end{array}$ & $\begin{array}{l}\mathrm{CC} \\
\mathrm{T} / \mathrm{C}\end{array}$ & $\begin{array}{l}\mathrm{RC} \\
\mathrm{T} / \mathrm{C}\end{array}$ \\
\hline \multirow{6}{*}{ Lifting work } & $\begin{array}{l}\text { Poor management of lifting objects } \\
\text { and control of surroundings }\end{array}$ & 0.0707 & 0.105 & 7 & 11 & 7 & 11 & 0 & 0 \\
\hline & Improper tying of the sling leg & 0.037 & - & 4 & - & 4 & - & 0 & - \\
\hline & Poor operator visibility & 0.107 & - & 11 & - & 11 & - & 0 & - \\
\hline & $\begin{array}{l}\text { Operator unable to check the weight } \\
\text { and specifications of the lifted objects }\end{array}$ & - & 0.103 & - & 10 & - & 10 & - & 0 \\
\hline & $\begin{array}{l}\text { Operator cannot check the wire and } \\
\text { sling leg }\end{array}$ & - & 0.057 & - & 6 & - & 6 & - & 0 \\
\hline & Subtotal & & & 22 & 27 & 22 & 27 & 0 & 0 \\
\hline \multirow{4}{*}{$\begin{array}{c}\text { Prime } \\
\text { contractor } \\
\text { management }\end{array}$} & $\begin{array}{l}\text { Inappropriate personnel and } \\
\text { equipment placement }\end{array}$ & 0.042 & 0.031 & 4 & 3 & 0 & 0 & 4 & 3 \\
\hline & $\begin{array}{l}\text { Poor subcontracting technology } \\
\text { management process }\end{array}$ & 0.084 & 0.065 & 8 & 7 & 0 & 0 & 8 & 7 \\
\hline & $\begin{array}{l}\text { Insufficient safety management of } \\
\text { equipment and personnel }\end{array}$ & 0.050 & 0.050 & 5 & 5 & 0 & 0 & 5 & 5 \\
\hline & Subtotal & & & 17 & 15 & 0 & 0 & 17 & 15 \\
\hline \multirow{5}{*}{$\begin{array}{l}\mathrm{T} / \mathrm{C} \\
\text { machinery }\end{array}$} & Equipment aging & 0.064 & 0.052 & 7 & 5 & 0 & 0 & 0 & 0 \\
\hline & Crane operation error or failure & 0.071 & 0.032 & 7 & 3 & 7 & 3 & 0 & 0 \\
\hline & $\begin{array}{l}\text { Problems with overseas parts } \\
\text { procurement }\end{array}$ & 0.075 & 0.083 & 8 & 8 & 0 & 0 & 8 & 8 \\
\hline & Subtotal & & & 22 & 16 & 7 & 3 & 8 & 8 \\
\hline & Total & & & 100 & 100 & 29 & 30 & 55 & 49 \\
\hline
\end{tabular}

\section{Discussion and Conclusions}

Despite various efforts to reduce accidents related to $\mathrm{T} / \mathrm{Cs}$, the number of accidents is still increasing. This study was conducted to help prevent $\mathrm{T} / \mathrm{C}$-related accidents by ranking the accident causes related to $\mathrm{CC} T / \mathrm{Cs}$ and $\mathrm{RC} \mathrm{T} / \mathrm{Cs}$, as well as the weights of each cause to be used as a reference for management. As shown in the results of our AHP questionnaire, various accidents occur when an operator cannot directly check the status or ties when a lifting object is hidden by other structures or objects, and is largely dependent on the signals and radio communications of other workers. The result of this study is "operator visibility" as first ranking cause in case of CC T/C, and is "operator unable to check the weight and specification of the lifting objects" as second ranking cause in case of RC T/C. In previous study [17], the operator's impact such as "operator proficiency", "operator character", and "employment source (operator)" was dominated. The collective weight of these causes is nearly $24 \%$. The cause of the tower crane "operator proficiency" was suggested as the second-level accident cause. Especially, the comprehensive cause of operator impact was suggested. The operator proficiency is an ambiguous cause of tower crane accidents. In other words, the way to solve this cause is ambiguous. To solve this cause, the operator training cycle in Korea has recently been shortened. In this study, operator visibility and to check lifting objects are very specific causes that can be managed and are suggested solutions at construction sites. Therefore, one could prevent tower accidents by attaching a device like RPSA to the jib or hook for both CC T/Cs and RC $\mathrm{T} / \mathrm{Cs}$. Such device could help T/C operators monitor their work from the cabin and make 
decisions based on signals from other workers and their own judgment. Additionally, it is necessary to train managers and workers continuously to help them maintain and comply with guidelines and manuals related to erection work, lifting work, and operation.

The major accident cause for CC T/Cs were ranked in descending order of "poor operator visibility", "bad bolting on the brace/mast/telescopic element", and "poor subcontractor technology". Such causes like "bad bolting on the brace/mast/telescopic element" and "poor subcontractor technology" are combined various factors such as the management problem of the prime contractor, the management problem of the subcontractor, and the skill of erecting/dismantling worker. The major accident cause for RC T/Cs were ranked in descending order of "poor management of lifting objects and control of surroundings", "operator unable to check the weight and specifications of lifting objects", and "failure to comply with safety rules and work guidelines". In particular, in the case of poor management of lifting objects and control of surroundings, there is a problem in the function of properly controlling and managing $\mathrm{T} / \mathrm{Cs}$ because cranes are controlled and managed by numerous operators who have completed the required training for each type of construction work. Therefore, it is recommended to have a separate manager in charge of supervising work using T/Cs at a construction site. Furthermore, the second major accident cause of checking the weight and specifications of lifting objects can be addressed by attaching RPSA to help operators to make informed decisions. This situation is similar to that of a CC T/C.

In previous study [17], the "site-level safety management" is the highest weight cause affecting safety on construction sites with tower crane. Especially, the superintendent effect has "superintendent character" and "site-level safety management" to influence the safety of the crane-related site, a total of over $23 \%$. In other previous study [20], as a result of analyzing the previous literature, the causal factors belonging to "site personnel management" are also very important as the frequency occupies the first to third place. In this study, most accident causes are related to situation/surrounding control using $\mathrm{T} / \mathrm{Cs}$ and management issues that require workers to comply with work guidelines and rules of erection, dismantling, and lifting works that reflect reality. Therefore, it is important to designate a safety manager of tower crane with sufficient experience and knowledge regarding $\mathrm{T} / \mathrm{Cs}$ to train $\mathrm{T} / \mathrm{C}$ operators, engineers, and managers, and to revise, supplement, and manage various instructions and manuals. Additionally, the safety manager of tower crane is expected to provide sufficient help in terms of reducing accidents through consistent safety-based management and exercising practical control authority over $\mathrm{T} / \mathrm{C}$ erection, telescoping, and lifting operations. In the case of an RC T/C, plans for supplemental education should be prepared as it becomes increasingly easy to obtain an operating license. In the field, it is necessary to establish a reinforced training plan for safety rules during erection, operation, and dismantling.

To prevent $\mathrm{T} / \mathrm{C}$ accidents, we derived the priorities of accident causes for different $\mathrm{T} / \mathrm{C}$ types using an AHP questionnaire. It is crucial to reduce accidents for sustainable management at construction sites. If the priorities of $\mathrm{T} / \mathrm{C}$ accident causes presented in this paper are utilized in various checklists or management plans, and construction site management is conducted accordingly, then sustainable construction management can be realized. In the future, if additional research is performed by narrowing the scope of AHP questionnaire respondents to workers who directly use $\mathrm{T} / \mathrm{Cs}$ and experts familiar with $\mathrm{T} / \mathrm{Cs}$, more realistic results can be derived, which will further reduce $\mathrm{T} / \mathrm{C}$ accidents.

\section{Limitations and Future Research}

This research was conducted to derive the priority of tower crane accident causes based on the experience of the related experts of construction sites with tower cranes. However, the effect was not verified by actual application to safety management plans or tower crane checklists at the real construction sites. Therefore, in the future research, it is necessary to apply the priority of accident causes based on expert experience to the 
practical example in accordance with the $\mathrm{T} / \mathrm{C}$ configuration to identify the actual accident reduction level.

Author Contributions: J.Y.K. reviewed the existing literature, completed the AHP questionnaire, and conducted the result data coding of AHP questionnaire and analysis.; D.S.L. analyzed the characteristics of each tower crane type and suggested a new tower crane safety model for application of the research results.; J.D.K. selected the subjects of the AHP questionnaire and conducted a AHP survey; G.H.K. conceived the whole this study and conducted a review of the research results. All authors have read and agreed to the published version of the manuscript.

Funding: No funding.

Institutional Review Board Statement: Not applicable.

Informed Consent Statement: Not applicable.

Data Availability Statement: The data presented in this study are available on request from the corresponding author. The data are not publicly available due to restrictions on right of privacy.

Conflicts of Interest: The authors declare no conflict of interest.

\section{References}

1. Shapira, A.; Lucko, G.; Schexnayder, C.J. Cranes for Building Construction Projects. J. Constr. Eng. Manag. 2007, 133, 690-700. [CrossRef]

2. Ministry of Land, Infrastructure and Transport. Available online: http:/ / kosis.kr (accessed on 27 July 2020).

3. Beavers, J.E.; Moore, J.R.; Rinehart, R.; Schriver, W.R. Crane-Related Fatalities in the Construction Industry. J. Constr. Eng. Manag. 2006, 132, 901-910. [CrossRef]

4. Choi, C.H. A Study on the Risk Analysis and Measures of Reduction through Tower Crane Accidents Cases. Master's Thesis, Hanyang University, Seoul, Korea, 2017.

5. The Korea Times. Available online: http://www.koreatimes.co.kr/www/nation/2020/02/281_281363.html (accessed on 3 November 2020).

6. Hinze, J.; Godfrey, R.; Sullivan, J. Integration of Construction Worker Safety and Health in Assessment of Sustainable Construction. J. Constr. Eng. Manag. 2013, 139, 594-600. [CrossRef]

7. Asanka, W.A.; Ranasinghe, M. Study on the impact of accidents on construction project. In Proceedings of the 6th International Conference on Structural Engineering and Construction Management 2015, Kandy, Sri Lanka, 11-13 December 2015; pp. 58-67.

8. Lee, H.S. A study on the Accident Analysis and the Control of Tower Cranes. Master's Thesis, Seoul National University of Science and Technology, Seoul, Korea, 2014.

9. Choi, S.-Y.; Cho, K.-H.; Park, D.-H.; Gil Choi, B. A study on the work environment and accident exposure status of Tower Crane workers. J. Korea Saf. Manag. Sci. 2015, 17, 115-123. [CrossRef]

10. Yun, D.H.; Jong, Y.P.; Jung, H.K. Measures to reduce tower crane accidents during operation by improving signal system and education for signalmen. J. Korea Saf. Manag. Sci. 2019, 34, 59-75. [CrossRef]

11. Ministry of Land, Infrastructure and Transport. Available online: http:/ / www.molit.go.kr (accessed on 27 July 2020).

12. Kim, Y.U. Problems and Improvement Schemes for Unmanned Tower Crane Accident through Case Analysis at Construction site. Master's Thesis, Chung-Ang University, Seoul, Korea, 2018.

13. Aneziris, O.; Papazoglou, I.; Mud, M.; Damen, M.; Kuiper, J.; Baksteen, H.; Ale, B.; Bellamy, L.; Hale, A.; Bloemhoff, A.; et al. Towards risk assessment for crane activities. Saf. Sci. 2008, 46, 872-884. [CrossRef]

14. Song, P.Y. A Study on Improvement of Safety Management through Analysis of Tower Crane Disaster at Construction Site. Master's Thesis, Pukyong University Safety Engineering, Seoul, Korea, 2018.

15. Kwon, O.M. Deduction of Accident Cause for Tower-Crane Using FMEA Method. Master's Thesis, Hanyang University, Seoul, Korea, 2015.

16. Richard, L.N.; Noah, S.S.; Kyle, K.R. A Review of crane safety in the construction industry. Appl. Occup. Environ. Mental Hyg. 2001, 16, 1106-1117. [CrossRef]

17. Shapira, A.; Simcha, M. AHP-Based Weighting of Factors Affecting Safety on Construction Sites with Tower Cranes. J. Constr. Eng. Manag. 2009, 135, 307-318. [CrossRef]

18. Cho, Y.R. Importance Evaluation of the Safety Accident Factors of Tower Crane Using Analytic Hierarchy Process. Master's Thesis, Kyonggi University, Suwon, Korea, 2017.

19. In, J.S. Factors that affect safety of tower crane installation/dismantling in construction industry. Saf. Sci. 2014, 72, 379-390. [CrossRef]

20. Zhang, X.; Zhang, W.; Jiang, L.; Zhao, T. Identification of Critical Causes of Tower-Crane Accidents through System Thinking and Case Analysis. J. Constr. Eng. Manag. 2020, 146, 04020071. [CrossRef]

21. Zhou, W.; Zhao, T.; Liu, W.; Tang, J. Tower crane safety on construction sites: A complex sociotechnical system perspective. Saf. Sci. 2018, 109, 95-108. [CrossRef] 
22. Fang, Y.; Cho, Y.K.; Chen, J. A framework for real-time pro-active safety assistance for mobile crane lifting operations. Autom. Constr. 2016, 72, 367-379. [CrossRef]

23. Chandra, H.P. Initial Investigation for Potential Motivators to Achieve Sustainable Construction Safety and Health. Procedia Eng. 2015, 125, 103-108. [CrossRef]

24. Rajendran, S.; Gambatese, J.; Behm, M. Impact of Green Building Design and Construction on Worker Safety and Health. J. Constr. Eng. Manag. 2009, 135, 1058-1066. [CrossRef]

25. Korea Occupational Safety and Health Agency. Available online: http://www.kosha.or.kr/kosha/data/construction.do (accessed on 27 July 2020).

26. Korea Occupational Safety and Health Agency. Safety Work Guide to Prevent Death of Construction Machinery and Equipment; Korea Occupational Safety and Health Agency: Seoul, Korea, 2018; pp. 1-97.

27. Cho, G.T.; Cho, Y.G.; Kang, H.S. The Analytic Hierarchy Process; Donghun: Seoul, Korea, 2003; pp. 1-311.

28. Tam, V.W.; Fung, I.W. Tower crane safety in the construction industry: A Hong Kong study. Saf. Sci. 2011, 49, 208-215. [CrossRef] 